\title{
Preface
}

Every book has its own story. Among its characters are loved ones, friends, and acquaintances, as well as archivists, librarians, editors-people whose help is indispensable to an academic project. Working on my previous books, I had always been conscious of the contributions of these others, but had never perceived them as essential. Somewhat self-importantly I ascribed authorship exclusively to myself. Courage and Fear is my most personal book-you would expect that it would not only be my most subjective, but also the one most intimately of my own making. It is, after all, an individual narrative that does not follow the convention of "scholarly objectivity." It steers clear of the tradition of invoking academic authorities. In my perception, however, it is precisely this book that owes the most to friends, with whom I was able to discuss individual chapters, and to others I was lucky to have met and who were willing to share their own perspective on both the present and the past. To mention them all would necessitate a personal second index. Allow me therefore to limit my acknowledgements to the initial readers and critics of the larger sections of my book: Bogumiła Berdychowska, Marta Bohachevsky-Chomiak, Marta Boianivska, Leonid Finberg, Timothy Snyder, Danuta Sosnowska, Stanisław Stępień, Vladyslav Verstiuk, and Kazimierz Wóycicki.

The idea for this project emerged a year after my mom passed away, my mother with whom I spoke too little, especially about the things that most interested me: composite ethnic identities, individual choices, and personal courage. In other words, matters that tend to determine our life's path. No one likes to talk about fear and it is no surprise that my family also avoided the subject, which was painful for both my parents.

My mother was born in Lviv at the start of World War II. She left her hometown in 1946 with the last transport of "repatriates" (Poles who had settled Eastern Galicia and other Eastern territories of the Second Polish Republic annexed by the Soviets in 1939), as Poland's borders shifted west and dramatic population swaps followed. In the fall of 2008, I decided to recruit friends and colleagues and organize an exhibit devoted to the first two years of 
World War II in Lviv. The exhibit would depict the experiences of various communities - Polish, Ukrainian, and Jewish - in the face of Soviet occupation. Despite various obstacles and unforeseen circumstances, eventually the project was realized. In July of 2010, after a year of preparations, Lvivians and tourists alike were able to view the first large Ukrainian exhibition hosted in a public space: Lviv's Market Square facing City Hall. Its authors were Oleh Pavlyshyn, of the Institute of Historical Research at the Ivan Franko National University of Lviv, and Mariusz Zajączkowski, of the Lublin branch of the Institute of National Remembrance. Magdalena Śladecka developed the art design, and Iaroslav Hrytsak, Rafał Wnuk, and myself served as academic consultants. The project came about because of the cooperation of the Polish Institute of National Remembrance, the Ukrainian Institute of Remembrance, and the embassy of the Republic of Poland in Kyiv. The Polish Institute's president, Janusz Kurtyka, its director, Agnieszka Rudzińska, and the vice-president of the Ukrainian Institute, Vladyslav Verstiuk, spared no effort in overcoming the obstacles in our path. Polish ambassador Jacek Kluczkowski supported the initiative, at the same time building a foundation for a new kind of dialogue between Polish and Ukrainian historians. Things turned out differently than expected, unfortunately. But discussions and arguments among authors, consultants, and patrons ultimately led to this book. On a personal note-although I had previously known each colleague at least by title-those months nourished our friendships.

A short while after the exhibit, it occurred to me that we barely touched on the issues I had set out to raise. The challenge was too weighty to address in the simplified format of an exhibition. It wanted something. I resolved to find a more adequate format to tell this immeasurably complex story. The work that followed resembled the typical research phase leading up to a book. It differed in one aspect, though: from the start I never intended to focus on unearthing new information, since the historical facts are well established. Recent years have seen the publication of several reference works, which I felt freed me from any duty to reiterate basic information. Moreover, in the course of the past dozen years historians have conducted intense research, substantially deepening our stores of knowledge about wartime Lviv, thus preempting the need to correct assertions and narrow down numbers, dates, or personal information. In this light, even new facts without a strikingly new interpretation do not amount to more than mere supplementation and ultimately cannot alter our current knowledge. Despite the existence of such an impressive body of contemporary scholarship, I chose not to rely exclusively on publications 
and documents in print. Instead, I delved into archival collections relatively unknown in Poland and underutilized even in Ukraine.

The fundamental goal I set for myself when I began writing was to refocus my story from a national to a personal narrative. Every national narrative dealing with an ethnic community is interested, above all, in the destinies of its "own" protagonists. An "other" may be allotted a limited part, but always under the condition of fitting into the existing canon. If this narrative perceives its "own" to be a victim, and the "other" an enemy, it assigns the respective roles from the start, making the nationalities of positive and negative protagonists easy to predict. No space remains for stories of cooperation, mutual support, or solidarity. National narratives treat each manifestation of those behaviors as exceptions that only prove the rule, without ever reframing the overall image. Even if those less standard stories are in fact exceptional, they deserve all the more attention. They attest to individual courage and to the human will to confront evil, even when faced with the threat of death. To view such actions purely as exceptions to the rule sheds light on our deeply rooted negative stereotypes. My personal experience, as well as my background in national identity studies, suggest that we cannot overcome stereotypes, because they are inherent to how we structure thought. I therefore set a more modest goal for myself: to show divergent patterns.

My choice of the main characters is not personal, albeit nearly all of them played a part in my life, the encounters occurring through family history, readings, films, or songs. What informed my selection above all else was the multifaceted and ambiguous aura these protagonists exude, their ideals and life stories, their survival strategies, and, finally, the accessibility of source materials about them. We can attribute their attitudes and relationships to their individual worldviews or their social origin in the educated elite. They functioned in Lviv's multinational community, which was admittedly ripe with conflict, yet not steeped in hatred. Under different circumstances - in short, had it not been for the abuses by functionaries of totalitarian regimes and by their underlings who in carrying out political visions bear a share of the responsibility for the Shoah and for crimes against humanity - ethnicity would have played only a minor role in their choices and life stories.

My aim was not to write an individual biography or focus on particular figures. Instead, I wanted to paint a picture of relationships among protagonists of different nationalities who happened to coinhabit occupied Lviv during the war. While each chapter has a key character, and the narrative spotlight falls on a particular life story, my main interest lies not in the sum of their 
biographies, but rather in the bonds tying them to their respective milieus. Hence the narrative does not follow along simple chronological lines of their lives or of the war. Although this more customary narrative frame would make for easier reading, it presents an obstacle when telling stories of intricate relationships. Instead of a linear narrative structure, characteristic for accounts based on chronology, I relied on nested storytelling. In a similar fashion, I chose not to construct my narrative around a simplifying plot. Thus, each chapter seeks not so much to solve a puzzle or ascertain a fact, as to establish the persons, events, and web of circumstances that came to influence a protagonist's strategy. To that end, I draw on a broad variety of documents of a personal nature (ego-documents): journals, memoirs, letters, third-person accounts, even interrogation transcripts. Other sources play only a secondary part. I make limited use of memoirs by Karolina Lanckorońska ${ }^{1}$ and Aleksander Wat, ${ }^{2}$ which are widely known and quoted in Polish scholarship. I applied a similar strategy to established Ukrainian and Jewish sources, such as the writings of poet Ostap Tarnavsky and the librarian and archeologist Larisa Krushelnytska, as well Kurt Lewin ${ }^{3}$ and Ignacy Chiger, ${ }^{4}$ to create a space for lesser-known or previously unquoted personal accounts.

While this book is not intended as a monograph devoted to Lviv's creative milieus, it was important to me to represent the life stories of representatives of various professions: doctors, scholars, writers, artists, and musicians. In tracing their mutual relationships, I show that they were not necessarily linked through narrow professional interests, and that these connections had a tendency to cross ethnic lines.

The majority of books about Lviv strike a nostalgic tone, which I made an effort to avoid. Yet just to invoke the complexity of this bygone world can evoke nostalgia.

1 Karolina Lanckorońska, a well-known art historian from a prominent aristocratic family, was among the first people to give testimony about the massacre of Lviv professors.

2 Aleksander Wat was a noted poet of the Polish avant-garde featured in Marci Shore's study of Polish leftist avant-garde poets Caviar and Ashes: A Warsaw Generations Life and Death in Marxism, 1918-1968 (New Haven: Yale University Press, 2006).

3 Kurt Lewin, the eldest son of Lviv rabbi Ezekiel Lewin, witness to the Holocaust, author of a number of memoirs.

4 Ignacy Chiger, the father of Krystyna Chiger-Keren, published a memoir Świat w mroku. Pamiętnik ojca dziewczynki w zielonym sweterku (Warsaw: PWN, 2011). His daughter's memoir The Girl in a Green Sweater: A Life in the Holocaust's Shadow (New York: St. Martin's Press, 2008) was adapted by Agnieszka Holland into a screenplay for the 2011 film W ciemności [In Darkness]. 
I would like to express my gratitude to the administration and the employees of the Shevchenko Scientific Society (New York), to the Lviv National Art Gallery, the Manuscript Collection of the National Library of Poland, the Manuscript Collection of the Warsaw University Library, the Central State Historical Archive in Lviv, the Kyiv-Mohyla Academy Archives, the Archive of the National University of Lviv, the State Archives Department of the Security Service of Ukraine, the Archive of the Ukrainian Academy of Arts and Sciences (New York), the Polish Academy of Sciences Archive (Warsaw), the Archive of the United States Holocaust Memorial Museum (Washington), and the Ossolineum Library (Wrocław). 


\section{Soga Savi!}

viaprawde, vardeo cierrymy siq 2 Lego, is odualastyónny adres

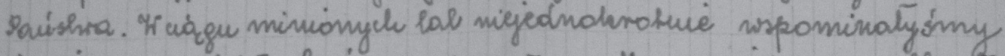

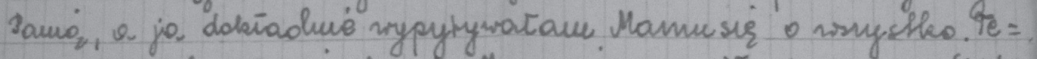

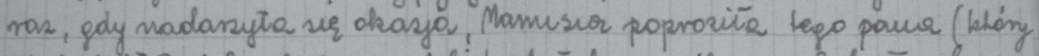
pdricokii Pauishre), any, jesieli to Mytaby mosiliwe, edobye adves. Miatyónny pretsasad psses p. Filipesalea lish do Tavi, ale nyjechal un niespodsieramie rise's niej, nir kierwotuie samiersai, nrge wi

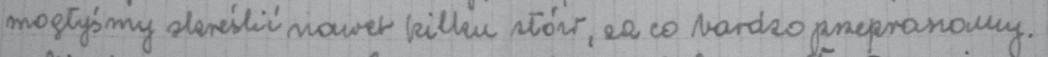

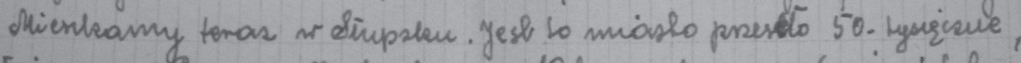

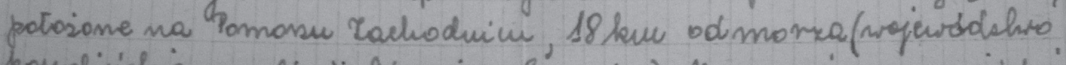

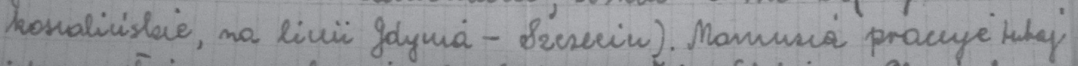

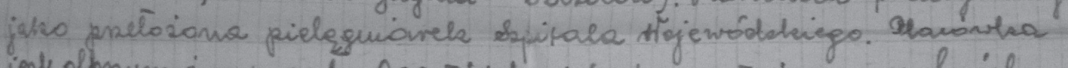
jost oltorymia - presibo 900 tósich i do tego potosiana w dwóch

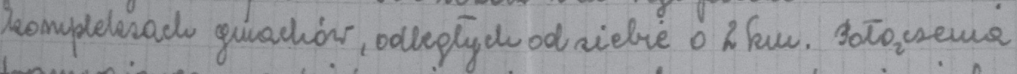
trammajowego ma hi trasie mi ma, ardvee rego traci is dusio

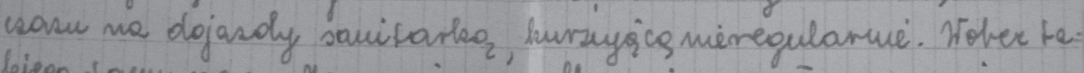

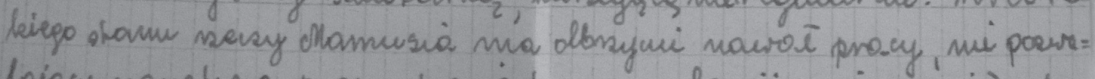

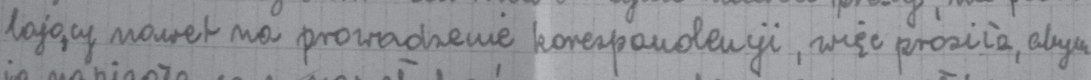

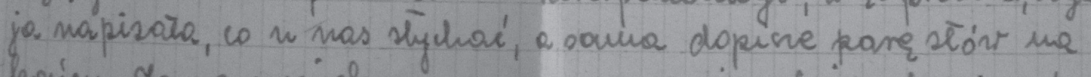
horien. Yo se avej shany prepranam, se nobre to dopiero he =

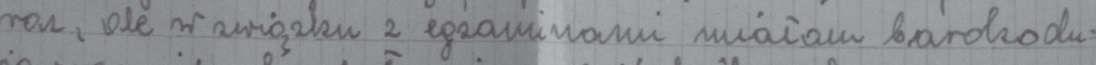

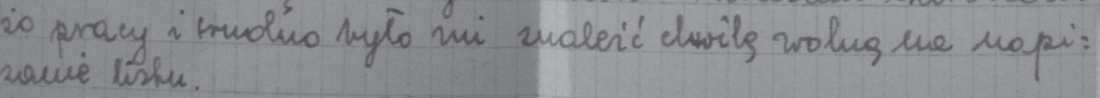

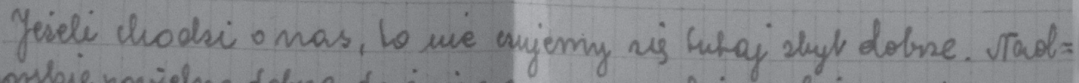
marskie fariehne dobne daje is man ne wabi - obie cirpiny uq

Letter from Halina Lewkowska to Iaroslava Muzyka, 1957 